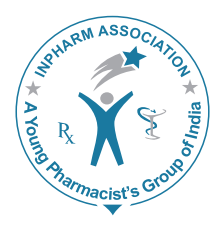

\title{
Anti-pyretic, anti-inflammatory, and analgesic effects of leaf extract of drumstick tree
}

\author{
Ayon Bhattacharya ${ }^{1 *}$, Manas Ranjan Naik, Divya Agrawal', Karmajeet Rath", \\ Sanjay Kumar ${ }^{1}$, Sudhanshu Sekhar Mishra ${ }^{1}$
}

\author{
${ }^{1}$ Department of Pharmacology, IMS \& SUM Hospital, SOA University, Bhubaneswar, Odisa, India, \\ ${ }^{2}$ Department of Anatomy, IMS \& SUM Hospital, SOA University, Bhubaneswar, Odisa, India
}

\begin{abstract}
Objectives: The aim was to investigate the antipyretic, anti-inflammatory and analgesic activity of ethanolic leaf extract of Moringa oleifera, commonly known as drumstick tree. Materials and Methods: The study is a randomized controlled experimental study. The experiments were carried out dividing the animals in six groups, each containing six animals. Ethanolic extract of Moringa M. oleifera (EMO was administered at 50,100,200, $400 \mathrm{mg} / \mathrm{kg}$ doses orally to the respective four groups. Control was normal saline (orally at $2 \mathrm{ml} / \mathrm{kg}$ body weight). Antipyretic activity was done in albino rats using the Brewer's yeast induced pyrexia model, standard used was paracetamol $(100 \mathrm{mg} / \mathrm{kg})$. Anti-inflammatory action was screened using carrageenan induced paw edema model in albino rats. Analgesic actions was evaluated using acetic acid induced writhing test and Eddy's hot plate test for the peripheral and central analgesic actions respectively using albino mice. Results: The ethanolic leaf extract of $M$. oleifera showed significant $(P<0.05)$ antipyretic and anti-inflammatory activities at 100,200 , $400 \mathrm{mg} / \mathrm{kg}$. The percentage inhibition of paw edema at $3^{\text {rd }} \mathrm{h}$ was $64.77 \%$ for aspirin and EMO $400 \mathrm{mg} / \mathrm{kg}$ showed $56.81 \%$ comparing with the control. Significant $(P<0.01)$ analgesic activity was exhibited by ethanolic leaf extract of $M$. oleifera at $100,200,400 \mathrm{mg} / \mathrm{kg}$ in both the acetic acid induced writhing test and the Eddy's hot plate test in comparison with control. Dose-dependent increase in the percentage inhibition of writhes was noted with EMO 100, 200, $400 \mathrm{mg} / \mathrm{kg}$ showing 26\%, $51 \%$ and $81 \%$, respectively. Conclusion: Thus, our study concludes that EMO leaves has antipyretic, anti-inflammatory, and both central and peripheral analgesic actions.
\end{abstract}

Key words: Acetic acid induced writhing test, analgesic, anti-inflammatory, antipyretic, Brewer's yeast, carrageenan, Eddy's hot plate method, Moringa oleifera

\begin{tabular}{|l|l|}
\hline \multicolumn{2}{|c|}{ Access this article online } \\
\hline \multirow{2}{*}{ Journal Sponsor } & $\begin{array}{l}\text { Website: } \\
\text { www.jyoungpharm.org }\end{array}$ \\
& $\begin{array}{l}\text { DOI: } \\
10.5530 / j y p .2014 .4 .4\end{array}$ \\
& \\
\hline
\end{tabular}

\section{INTRODUCTION}

*Address for correspondence:

Dr. Ayon Bhattacharya, Department of Pharmacology, IMS \& SUM Hospital, B.O. Ghatikia, Bhubaneswar - 751 003, Odisha, India.

E-mail: ayonbhattacharya@yahoo.in. 
declared by $\mathrm{WHO}$ as promotive, preventive, curative and rehabilitative and can serve as an alternative in this regard. ${ }^{1}$ The present study was carried out on the plant known since antiquity named Moringa oleifera, to screen the analgesic, anti-inflammatory, and antipyretic effects.

M. oleifera, Moringa pterygosperma (Family-Moringaceae) is native of south Asia, now grown worldwide. It is known as drumstick or Horseradish tree in English, Sahijan in Sanskrit, Mungna in Hindi, Sajna in Oriya, Sojne danta in Bengali. ${ }^{2}$ It is a small medium sized, fast growing tree grown in hot arid regions and thrives well even in drought. The leaves are highly nutritious and a good source of beta carotenes, amino acids (methionine, cysteine, tryptophan, lysine), vitamin $C$, vitamin $B_{1}$, vitamin $B_{2}$, vitamin $B_{3}$, iron, potassium, calcium, zinc, sodium and also a potential source of natural antioxidants. ${ }^{3}$ Apart from the nutritious leaves, there also has been many folklore claims about this plant. The history of this plant dates back to almost 5000 years back and is documented in writings of the Romans, Egyptians and the Charaka samhita. ${ }^{4}$ The leaves of $M$. oleifera were used as a poultice for sores, stomachaches, headaches and by African bushmen for rheumatic joint pain. ${ }^{5}$

The previous phytochemical studies revealed the presence of flavonoids, anthocyanin, cinnamates and proanthocyanidins, 4-hydroxymellein, $B$-sitosterol, vanillin. ${ }^{6}$ The leaves have a number of central nervous system (CNS) activities such as anticonvulsant, antidepressant and neuroprotective in Alzheimer's disease, anti-asthmatic, hypocholesterolemic, wound healing, CNS depressant antispasmodic, hepatoprotective, antihyperglycemic, antifertility, anti-ulcer, and antihypertensive. ${ }^{6}$ The present study was done to evaluate analgesic, anti-inflammatory and antipyretic effect of ethanolic leaf extract of $M$. oleifera on albino rats and mice. In this article, the botanical name of "drumstick tree," which is M. oleifera shall be used in all sections.

\section{MATERIALS AND METHODS}

\section{Materials}

\section{Collection of plant material}

Fresh leaves were collected from Chandaka forest near IMS and SUM Hospital, Bhubaneswar, Odisha - 751003 and its identity was confirmed by scientists of the Orissa University of Agriculture and Technology, Bhubaneswar.

\section{Preparation of extract}

Leaves of $M$. oleifera were collected, dried in the shade and later made into powder. $90 \%$ ethanol was used to extract the powder using the method of soxhlation for $18 \mathrm{~h}$. Whitman filter paper No. 1 was used to filter the extract and concentrated to yield a semi solid mass of $46 \mathrm{~g}$ (yield $9.2 \% \mathrm{w} / \mathrm{w}$ ). Extract was refrigerated at $4{ }^{\circ} \mathrm{C}$ and used later.

\section{Chemicals}

Morphine (Morphitroy, Troikaa Pharmaceuticals Limited, Gujarat, India), acetic acid (Fischer Inorganic and Aromatic Limited, Chennai, India), Diclofenac (Voveran, Novartis, Worli, Mumbai), aspirin (Burgoyne Burbidges and Co, India), carrageenan (Sd Fine-Chem Limited, India), paracetamol (Dr. Reddy's Laboratory, Hyderabad), yeast extract powder (HiMedia Laboratories Private Limited, Mumbai, India), other solvent chemicals used were of analytical grade.

\section{Animals}

Animals were procured from central animal house IMS \& SUM Hospital. Wistar Albino rats (100-200 g) and mice (20-30 g) of either sex were used. Food, water given ad libitum. Animals were acclimatized to laboratory conditions for 7 days before the experiments. The study was approved by the Institutional Animal Ethical Committee (IAEC) of Siksha O Anusandhan University, Bhubaneswar under the approval number 22/12/IAEC/SPS/SOA.

\section{Methods}

Brewer's yeast induced pyrexia: Totally 60 rats were taken, dividing them into six groups, each containing 10 rats. Ethanolic extract of Moringa oleifera (EMO) was administered at $50,100,200,400 \mathrm{mg} / \mathrm{kg}$ doses orally to the respective four groups. Control group was fed with normal saline at $2 \mathrm{ml} / \mathrm{kg}$. 20\% suspension of Brewer's yeast in normal saline was injected subcutaneously at a dose of $10 \mathrm{ml} / \mathrm{kg}$ body weight below the nape of the neck of rats in all groups. Pyrexia developed after $10 \mathrm{~h}$ of Brewer's yeast injection and the temperatures recorded. Animals that showed a rise in body temperature to at least $39^{\circ} \mathrm{C}$ were included in the study, allowing a minimal of six rats in each group, total of 36 rats. Drugs were given after development of pyrexia and temperatures recorded at 0 , $0.5,1$ and $2 \mathrm{~h}$. Paracetamol at $100 \mathrm{mg} / \mathrm{kg}$ orally was taken as the standard drug. The maximum reduction in average rectal temperature in comparison with the control group was calculated and compared.

Carrageenan induced rat paw edema test: The animals were randomly divided into six groups with six rats each; 
Group I: Control (normal saline given orally at $2 \mathrm{ml} / \mathrm{kg}$ body weight); Group II: Standard (aspirin at $200 \mathrm{mg} / \mathrm{kg}$ ); Group III, IV, V, VI (EMO 50, 100, 200, $400 \mathrm{mg} / \mathrm{kg}$ respectively). The EMO, and the standard drug were administered by oral route after making suspension with tween 80. One hour later the rats were challenged with subcutaneous injection of $0.1 \mathrm{ml}$ of $1 \%$ solution of carrageenan on the plantar surface of the left hind paw and the right hind paw served as control. The paw was marked with ink at the level of the lateral malleolus and immersed in the water chamber of the digital plethysmometer for measuring paw volume. The paw volume was measured before and after carrageenan injection at 0 and $3 \mathrm{~h}$. The efficacy of the drug was tested on its ability to inhibit paw edema. The increase in paw edema is calculated as a percentage compared with the basal paw volume. The formula used for calculating the percentage inhibition of paw edema is as follows: ${ }^{7}$

Percentage of inhibition $=(\mathrm{Vc}-\mathrm{Vt} / \mathrm{Vc}) \times 100$.

$\mathrm{Vc}=$ Paw edema in control group

$\mathrm{Vt}=$ Paw edema in test groups

\section{Analgesic activity}

Acetic acid induced writhing method: The extract was given orally $1 \mathrm{~h}$ before, and standard drug diclofenac $(10 \mathrm{mg} / \mathrm{kg})$ was given intraperitoneally $1 / 2 \mathrm{~h}$ before the administration of acetic acid. On intra-peritoneal injection of acetic acid $1 \%, 10 \mathrm{ml} / \mathrm{kg}$ a characteristic response called the writhing syndrome was observed. This syndrome is characterized by a series of abdominal muscle contraction, extension of hind limbs, twisting and turning movements of the body, opisthotonos. ${ }^{8}$ This behavior was observed after $5 \mathrm{~min}$ of administration of acetic acid and counted for total $10 \mathrm{~min}$ before and after the administration of the drug. The results were expressed as percentage protection of writhes comparing with the control.

Eddy's hot plate method: Albino mice were placed on a heated copper plate set at $55 \pm 1{ }^{\circ} \mathrm{C}$ and the time taken for either to sit on its hind paw and blow its forepaw paw was taken as the reaction time or latency time. The test drug (EMO) was administered orally $1 \mathrm{~h}$ before, and the standard drug morphine $(1 \mathrm{mg} / \mathrm{kg})$ was given intraperitoneally $1 / 2$ $\mathrm{h}$ prior to the experiment. The cut-off period was taken at $15 \mathrm{~s}$. The latency time was recorded at $0,60 \mathrm{~min}$ of administration of standard and test drug. ${ }^{9}$

\section{Statistics}

The results of this study were tabulated using one-way ANOVA, followed by Dunnett's post-hoc test. Level of significance was taken at $P<0.05$. The results are displayed as Mean \pm standard deviation.

\section{RESULTS}

The Brewer's yeast induced pyrexia model is a classical method for screening antipyretic action of plant extracts. The ethanolic leaf extract of $M$. oleifera showed significant $(P<0.05)$ antipyretic activity at $100,200,400 \mathrm{mg} / \mathrm{kg}$. Paracetamol showed significant $(P<0.01)$ antipyretic activity from $0.5 \mathrm{~h}$ of drug administration upto $2 \mathrm{~h}$. EMO at a dose of $50 \mathrm{mg} / \mathrm{kg}$ did not show antipyretic effect. EMO $100 \mathrm{mg} / \mathrm{kg}$ showed significant $(P<0.05)$ action from $2 \mathrm{~h}$ and that for $200 \mathrm{mg} / \mathrm{kg}$ and $400 \mathrm{mg} / \mathrm{kg}$ from $0.5 \mathrm{~h}$ (Table 1).

Table 2 shows the effect of EMO and aspirin on paw volume edema at different hours. Significant reduction $(P<0.01)$ of paw edema was shown by aspirin and EMO $(100,200,400 \mathrm{mg} / \mathrm{kg})$. Figure 1 shows the percentage inhibition of paw edema by aspirin and EMO at different hours compared with the control. The percentage inhibition of paw edema at $3^{\text {rd }} \mathrm{h}$ was $64.77 \%$ for aspirin and EMO $400 \mathrm{mg} / \mathrm{kg}$ showed $56.81 \%$ comparing with the control.

The ethanolic leaf extract of $M$. oleifera showed significant $(P<0.05)$ analgesic activity in both the models showing a gradually increasing effect with an increase in dose (100, $200,400 \mathrm{mg} / \mathrm{kg}$ ). The results of the acetic acid induced writhing test along with the percentage inhibition of writhes are given in Table 3. Dose-dependent increase in the percentage inhibition of writhes was noted with EMO 100, $200,400 \mathrm{mg} / \mathrm{kg}$ showing $26 \%, 51 \%$ and $81 \%$ respectively. The result of EMO $400 \mathrm{mg} / \mathrm{kg}$ is almost comparable with the results with diclofenac. In Eddy's hot plate EMO

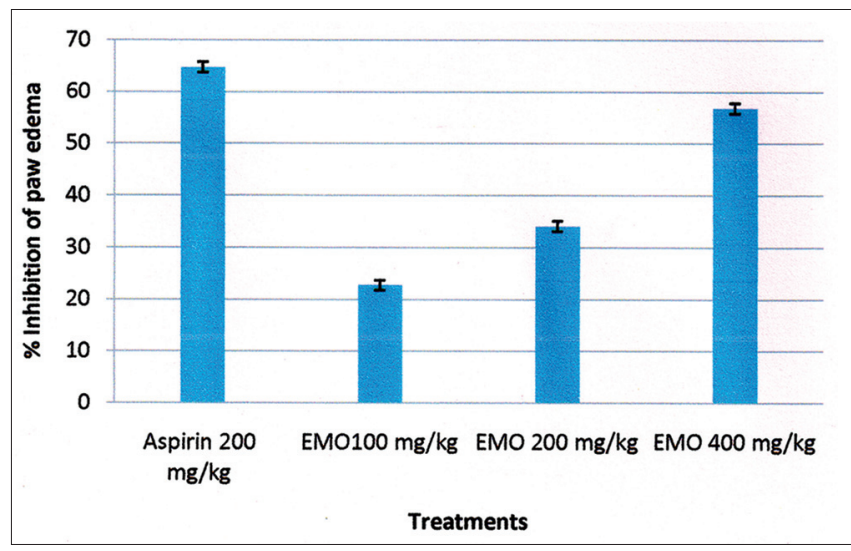

Figure 1: Percentage inhibition of paw edema of ethanolic extract of Moringa oleifera and aspirin at $3 \mathrm{~h}$ in carrageenan induced rat paw edema model

Journal of Young Pharmacists Vol 6 • Issue 4 • Oct-Dec 2014 
Bhattacharya, et al.: Antipyretic, anti-inflammatory, and analgesic activities of drumstick tree

Table 1: Effect of paracetamol and EMO on yeast induced pyrexia using one way ANOVA followed by post-hoc Dunnett's test

\begin{tabular}{|c|c|c|c|c|c|}
\hline \multirow[t]{2}{*}{ Groups } & \multicolumn{5}{|c|}{ Rectal temperature after $10 \mathrm{~h}$ of Brewer's yeast injection in ${ }^{\circ} \mathrm{C}$} \\
\hline & BBT & $\mathrm{Oh}$ & $0.50 \mathrm{~h}$ & $1 \mathrm{~h}$ & $2 \mathrm{~h}$ \\
\hline Control & $37.16 \pm 0.17$ & $39.18 \pm 0.13$ & $39.28 \pm 0.30$ & $39.41 \pm 0.33$ & $39.33 \pm 0.45$ \\
\hline Standard (paracetamol $100 \mathrm{mg} / \mathrm{kg}$ ) & $37.16 \pm 0.34$ & $39.2 \pm 0.16$ & $38.46 \pm 0.39^{* *}$ & $37.8 \pm 0.62^{* * *}$ & $37.06 \pm 0.38^{* * *}$ \\
\hline EMO $50 \mathrm{mg} / \mathrm{kg}$ & $37.28 \pm 0.21$ & $39.28 \pm 0.19$ & $39.25 \pm 0.19$ & $39.13 \pm 0.16$ & $39.16 \pm 0.12$ \\
\hline EMO $100 \mathrm{mg} / \mathrm{kg}$ & $37.08 \pm 0.18$ & $39.23 \pm 0.12$ & $39.05 \pm 0.15$ & $38.95 \pm 0.13$ & $38.66 \pm 0.15^{\star}$ \\
\hline EMO $200 \mathrm{mg} / \mathrm{kg}$ & $37.18 \pm 0.26$ & $39.15 \pm 0.18$ & $38.85 \pm 0.37^{*}$ & $38.73 \pm 0.54^{*}$ & $38.48 \pm 0.48^{\star *}$ \\
\hline $\mathrm{EMO} 400 \mathrm{mg} / \mathrm{kg}$ & $37.16 \pm 0.12$ & $39.25 \pm 0.16$ & $38.83 \pm 0.33^{*}$ & $38.56 \pm 0.35^{\star *}$ & $38.15 \pm 0.37^{* * *}$ \\
\hline
\end{tabular}

Table 2: Effect of EMO and standard drug (aspirin) at $0 \mathrm{~h}$ and $3 \mathrm{~h}$ post-carrageenan administration with their percentage inhibition of paw edema (ANOVA followed by post-hoc Dunnett's test)

\begin{tabular}{lccc}
\hline Treatments & $\mathbf{O h}$ & $\mathbf{3 ~ h}$ & $\begin{array}{c}\text { Percentage } \\
\text { inhibition of paw } \\
\text { edema at } \mathbf{~ h}\end{array}$ \\
\hline Normal saline $2 \mathrm{ml} / \mathrm{kg}$ & $0.11 \pm 0.01$ & $0.88 \pm 0.04$ & \\
Aspirin $200 \mathrm{mg} / \mathrm{kg}$ & $0.1 \pm 0.01$ & $0.31 \pm 0.03^{\star *}$ & 64.77 \\
EMO $50 \mathrm{mg} / \mathrm{kg}$ & $0.1 \pm 0.01$ & $0.9 \pm 0.08$ & \\
EMO $100 \mathrm{mg} / \mathrm{kg}$ & $0.1 \pm 0.01$ & $0.68 \pm 0.06^{* *}$ & 22.72 \\
EMO $200 \mathrm{mg} / \mathrm{kg}$ & $0.1 \pm 0.01$ & $0.58 \pm 0.08^{* *}$ & 34.09 \\
EMO $400 \mathrm{mg} / \mathrm{kg}$ & $0.11 \pm 0.01$ & $0.38 \pm 0.04^{* *}$ & 56.81 \\
\hline
\end{tabular}

Results are expressed as mean \pm standard deviation $(n=6) .{ }^{*} P<0.05$ when compared to control. ${ }^{\star \star} P<0.01$ when compared to control, EMO: Ethanolic extract of Moringa oleifera

Table 3: Analgesic effect of EMO and diclofenac on acetic acid induced writhing test (ANOVA followed by post-hoc Dunnett's test)

\begin{tabular}{lcc}
\hline Treatments & $\begin{array}{c}\text { Number of writhes } \\
\text { (mean } \pm \text { SD) }\end{array}$ & $\begin{array}{c}\text { Percentage } \\
\text { of inhibition }\end{array}$ \\
\hline Control & $56.83 \pm 2.56$ & \\
Diclofenac & $10.16 \pm 1.60^{* * *}$ & 82 \\
EMO $50 \mathrm{mg} / \mathrm{dl}$ & $56.00 \pm 5.23$ & 1 \\
EMO $100 \mathrm{mg} / \mathrm{dl}$ & $41.66 \pm 1.86^{* * *}$ & 26 \\
EMO $200 \mathrm{mg} / \mathrm{dl}$ & $27.5 \pm 4.08^{* * *}$ & 51 \\
EMO $400 \mathrm{mg} / \mathrm{dl}$ & $10.66 \pm 3.32^{* * *}$ & 81 \\
\hline
\end{tabular}

Results are tabulated as mean $\pm \mathrm{SD}(n=6),{ }^{*} P<0.05,{ }^{\text {** }} P<0.01,{ }^{* * *} P<0.001$. EMO: Ethanolic extract of Moringa oleifera, SD: Standard deviation

showed significant $(P<0.05)$ increase in the reaction time along with morphine (Table 4).

\section{DISCUSSION}

Brewer's yeast here is an exogenous pyrogen (lipopolysaccharide that is the cell wall component of Gram-negative bacteria), which causes pathogenic fever by binding to lipopolysaccharide binding protein thus resulting in the release of cytokines like interleukin (IL1), IL6, tumor necrosis factor alpha (TNF- $\alpha$ ) and ultimately prostaglandings. ${ }^{10}$ These pro-inflammatory mediators cross the blood brain barrier and act on the pre-optic/anterior hypothalamus triggering the release of prostaglandin $\mathrm{E}_{2}$ $\left(\mathrm{PGE}_{2}\right)$ produced from $(\mathrm{COX})-2$ and thus elevating the body temperature. The anti-inflammatory activity of M. oleifera is attributed to its cyclooxygenase inhibitory
Table 4: Analgesic effect of EMO and morphine on Eddy's hot plate test $($ mean \pm SD) using ANOVA followed by post-hoc Dunnett's test

\begin{tabular}{lcc}
\hline Group & 0 min & $60 \mathrm{~min}$ \\
\hline Control (saline $2 \mathrm{ml} / \mathrm{kg})$ & $1.66 \pm 0.51$ & $1.83 \pm 0.40$ \\
Standard (morphine $1 \mathrm{ml} / \mathrm{kg})$ & $1.66 \pm 0.51$ & $10.5 \pm 1.04^{\star * *}$ \\
EMO $50 \mathrm{mg} / \mathrm{kg}$ & $1.83 \pm 0.40$ & $1.66 \pm 0.51$ \\
EMO $100 \mathrm{mg} / \mathrm{kg}$ & $1.83 \pm 0.40$ & $5.00 \pm 1.09^{\star * *}$ \\
EMO $200 \mathrm{mg} / \mathrm{kg}$ & $1.66 \pm 0.51$ & $7.16 \pm 0.75^{\text {***}}$ \\
EMO $400 \mathrm{mg} / \mathrm{kg}$ & $1.83 \pm 0.40$ & $9.66 \pm 0.81^{\text {***}}$ \\
\hline
\end{tabular}

${ }^{*} P<0.05,{ }^{* *} P<0.01,{ }^{\star * \star} P<0.001$. EMO: Ethanolic extract of Moringa oleifera, SD: Standard deviation

activity. ${ }^{11}$ The phytochemical ingredients in the leaf extract such as phenolics, flavonoids, tannins, saponins, and terpenoids could be responsible for the antipyretic activity of this plant. ${ }^{12}$

Inflammation is characterized in phases, the first phase by vascular permeability, exudation of plasma, release of mediators; the second phase is due to migration of leucocytes and the final phase is by granuloma formation. ${ }^{13}$ This study is a subacute study using carrageenan as a phlogistic agent. The paw edema induced by carrageenan in rats is biphasic, the first phase $(0-1 \mathrm{~h})$ due to release of 5-HT, histamine, bradykinin from mast cells, plateau phase $(2 \mathrm{~h})$ maintained by kinins, second phase $(3 \mathrm{~h})$ produced by prostaglandins, protease and lysosomes. ${ }^{14}$ In this study ethanolic leaf extract of $M$. oleifera showed significant $(P<0.01)$ reduction of paw edema at $100,200,400 \mathrm{mg} / \mathrm{kg}$ in the $3^{\text {rd }} \mathrm{h}$ compared with control suggesting that the extract predominantly inhibited the release of prostaglandin like substances. The anti-inflammatory activity of ethanolic leaf extract of $M$. oleifera may be attributed due to the phytochemical ingredients in it like flavonoids, 4-hydroxymellein, $\beta$ sitosterol and vanillin. ${ }^{12}$ Flavonoids play a major role here as it not only inhibits prostaglandin biosysnthesis, but inhibiting endoperoxidases but also enzymes like protein kinases and phosphodiesterases that are involved in the inflammation process. ${ }^{15,16}$

In the analgesic study, EMO showed significant $(P<0.05)$ results in both the experimental models showing both 
central and peripheral anti-nociceptive actions. In the peripheral analgesic model that is acetic acid induced test, increased level of prostanoids, particularly $\mathrm{PGE}_{2}$, $\mathrm{PGF}_{2}$, bradykinin, serotonin, lipoxygenase products are released due to activation of chemosensitive nociceptors by the peritoneal injections of acetic acid. ${ }^{9}$ Recently it has been found that nociceptive activity of acetic acid could be due to release of cytokines like TNF- $\alpha$, IL-1 $\beta$, IL- 8 by the macrophages and mast cell in the peritoneum. ${ }^{17}$ This test confirms the anti-nociceptive action of EMO, which could be due to inhibition of prostaglandin synthesis. There is also a possibility that the anti-nociceptive action of EMO could be due to inhibition of cytokines like TNF- $\alpha$, IL-1 $\beta$, IL-8, however this needs to be confirmed by further studies.

In Eddy's hot plate test, EMO increased the latency time to discomfort in rats. This model is used to screen the central analgesic effect in animal models. Here we can postulate that EMO acts via the periaqueductal gray matter to release endogenous peptides (endorphins or encephalins). ${ }^{9}$ These peptides descend and act on the spinal cord to inhibit the pain impulses in the dorsal horn. Phytochemical ingredients like flavonoids, saponins, tannins, terpenoids could contribute to its analgesic action. ${ }^{12}$

\section{CONCLUSION}

The present study showed antipyretic, anti-inflammatory, and analgesic actions of EMO leaf. However, further research is needed to explore the active ingredients contributing to its activities and to highlight the exact mechanism of action of this plant.

\section{ACKNOWLEDGMENT}

I would like to extend my utmost gratitude to Dr. Ananya Chakraborty, Associate Professor, Department of Pharmacology, VIMS \& RC, Bengaluru. I am also grateful to Dr Gautam Ghosh, SPS, SOA University for his cooperation and support.

\section{REFERENCES}

1. Gupta M, Banerjee D, Mukerjee A. Studies of, anti-inflammatory, antipyretic and analgesic effects of aqueous extracts of traditional herbal drugs on rodents. Int Res J Pharm. 2013;4:113-20.

2. Awanish P, Rishabh DP, Tripathi P, Gupta PP, Jamal H, Bhatt S, et al. Moringa oleifera Lam. (Sahijan) - A plant with a plethora of diverse therapeutic benefits: An updated retrospection. Med Aromat Plant. 2001;1:1-8.

3. Mehta J, Shukla A, Bukhariya V, Charde R. The magic remedy of Moringa oleifera: An overview. Int J Biomed Adv Res. 2011;2:215-27.

4. Dahanukar SA, Kulkarni RA, Rege NN. Pharmacology of medicinal plants and natural products. Indian J Pharmacol. 2000;32:81-118.

5. Homa M, Soheila J, Jalal Z, Shamsali R, Reza T. Analgesic effects of methanolic extracts of the leaf or root of Moringa oleifera on complete Freund's adjuvant-induced rheumatoid arthritis in rats. J Chin Integr Med. 2011;9:216-22.

6. Goyal BR, Agrawal BB, Goyal RK, Mehta AA. Phyto-pharmacology of Moringa oleifera lam an overview. Nat Prod Radiance. 2007;6:347-53.

7. Hegde SV, Yarappa RL, Rai PS. Anti-inflammatory and analgesic activities of stem bark extracts of Eugenia jambolana. J Pharmacol Pharmacother. 2011;2:202-4.

8. Siegmund E, Cadmus R, Lu G. A method for evaluating both non-narcotic and narcotic analgesics. Proc Soc Exp Biol Med. 1957;95:729-31.

9. Bhattacharya A, Agrawal D, Sahu PK, Kumar S, Mishra SS, Patnaik S. Analgesic effect of ethanolic leaf extract of Moringa oleifera on albino mice. Indian J Pain. 2014;28:89-94.

10. Saper CB, Breder CD. The neurologic basis of fever. N Engl J Med. 1994;330:1880-6.

11. Venkateshwara KN, Gopalakrishnan V, Loganathan V. Antiinflammatory action of Moringa oleifera lam. Anc Sci Life. 1999;18:195-8.

12. Vinoth B, Manivasagaperumal R, Balamurugan S. Phytochemical analysis and antibacterial activity of Moringa oleifera lam. Int J Res Biol Sci. 2012;2:98-102.

13. Harsh M. Textbook of Pathology. $6^{\text {th }}$ ed. New Delhi: Jaypee Brothers Medical Publishers (P) Ltd.; 2010. p. 130.

14. Adeyemi OO, Okpo SO, Okpaka O. The analgesic effect of the methanolic extract of Acanthus montanus. J Ethnopharmacol. 2004;90:45-8.

15. Moroney MA, Alcaraz MJ, Forder RA, Carey F, Hoult JR. Selectivity of neutrophil 5-lipoxygenase and cyclo-oxygenase inhibition by an antiinflammatory flavonoid glycoside and related aglycone flavonoids. J Pharm Pharmacol. 1988;40:787-92.

16. Kumar D, Kumar S, Singh J, Narender, Rashmi, Vashistha B, et al., Free Radical Scavenging and Analgesic Activities of Cucumis sativus L. Fruit Extract. J Young Pharm. 2010;2:365-8.

17. Ribeiro RA, Vale ML, Thomazzi SM, Paschoalato AB, Poole S, Ferreira SH, et al. Involvement of resident macrophages and mast cells in the writhing nociceptive response induced by zymosan and acetic acid in mice. Eur J Pharmacol. 2000;387:111-8. 